\title{
(POSSIBLE) IMPACT OF CETA ON CREATION OF LAW ${ }^{1}$
}

\author{
Ondrej Blažo \\ Comenius University in Bratislava, Faculty of Law
}

\begin{abstract}
The paper brings an analysis, and possible solutions, regarding "threats" to regulatory sovereignty of the parties to the CETA. Hence technical trade barriers, sanitary and phytosanitary measures, regulatory cooperation, liberalization of services and protection of investors are focal points for estimating future development of legal regime in both the EU and Canada. The analysis assesses only "possible" impact of the CETA because it will be subject to ratification and the outcome of this process is insecure.
\end{abstract}

Key words: CETA, commercial policy, European Union, Canada, investment

\section{INTRODUCTION}

After civil protests, hesitation of Wallonia, as well as efforts to obtain judicial injunction preventing its signature at Federal Constitutional Court of Germany, the Comprehensive Economic and Trade Agreement (CETA) between the European Union and its member states as a one party and Canada as other party was finally signed in Brussels on 28 October 2016. Major doubts regarding this treaty focused on possible losing regulatory sovereignty of EU's member states, favouring transnational corporations in regulation procedures, and mainly offsetting democratic principles via the dispute-settlement system in state-investor claims. As a partial response for these discussions, the following article will bring an analysis, and possible solutions, regarding aforementioned "threats" to regulatory sovereignty of the parties to the CETA. Hence technical trade barriers, sanitary and phytosanitary measures, regulatory cooperation, liberalization of services and protection of investors are focal points for estimating future development of legal regime in both the EU and Canada. The analysis assesses only "possible" impact of the CETA because it will be subject to ratification and the outcome of this process is insecure.

\section{TECHNICAL REGULATORY BARRIERS}

Technical regulations can on the one hand constitute obstacles to free movement of goods between states, on the other hand they represent a tool ensuring protection of market of particular state against goods that can be harmful for consumers, infrastructure, can lead to mutual incompatibility of goods sold on a particular market, etc. Therefore, standardization is an effective measure for the effectiveness of market in favour of industry and final consumers, too, but also a tool of open or hidden discrimination or limitation of import.

First of all it must be noted, that the CETA incorporates Agreement on Technical Barriers to Trade (TBT Agreement) that is an annex of WTO Agreement. ${ }^{2}$ Being a party of WTO Agreement,

1 The article was prepared within project VEGA 2/0109/16 Institutional competitiveness in the light of changes of external environment.

2 CETA, Art. 4.2. 
cooperation in technical barriers is nihil novum sub sole for the EU and its members, as well as Canada. Basic principles of technical barriers can be read in Art. 2 TBT Agreement:

a) national treatment, i.e. products originated from other country are subject to technical regulations that are not less favourable than those covering domestic products;

b) necessity and legitimacy of regulation, i.e. technical regulations are not prepared, adopted or applied with a view to or with the effect of creating unnecessary obstacles to international trade and shall not be more trade-restrictive than necessary to fulfil a legitimate objective, taking account of the risks non-fulfilment would create; such legitimate objectives are, inter alia: national security requirements; the prevention of deceptive practices; protection of human health or safety, animal or plant life or health, or the environment.

c) time and condition adaptiveness, i.e. technical regulations shall not be maintained if the circumstances or objectives giving rise to their adoption no longer exist or if the changed circumstances or objectives can be addressed in a less trade-restrictive manner.

d) internationalization of standards, i.e. where technical regulations are required and relevant international standards exist or their completion is imminent, they or the relevant parts of them shall be used as a basis for their technical regulations except when such international standards or relevant parts would be an ineffective or inappropriate means for the fulfilment of the legitimate objectives pursued, for instance because of fundamental climatic or geographical factors or fundamental technological problems.

The CETA does not incorporate procedural provisions of the TBT and introduces its own rules of cooperation. Although the parties of the CETA committed themselves to cooperate in areas of standards and technical regulation (Cf regulatory cooperation) ${ }^{3}$, aim to mutual compatibility ${ }^{4}$, as well as follow conformity procedures ${ }^{5}$, it is obvious that Canada and the EU are allowed to maintain their respective technical regulations. The CETA, hence, does not mean creation of a single market including Cassis-de-Dijon-like automatic market-acceptance of goods produced under the regulations of the respective country.

Nevertheless, Canada and the EU committed themselves "to cooperate to the extent possible, to ensure that their technical regulations are compatible with one another", however this legal duty can be hardly considered mandatory harmonization or duty to lower requirements of technical standards. The cooperation and harmonization can be described more as a mutual inspiration than an obligation to find the common denominator. ${ }^{6}$ Mutual recognition of standards and mutual acceptance of the results of conformity assessment follow up Agreement on Mutual Recognition between the European Community and Canada of 1998 and it can be noted that it explicitly does not cover the agriculture sector. ${ }^{7}$ It is obvious that mutual recognition of accredited conformity assessment bodies does not mean mutual recognition of technical standards.

The CETA does not remove technical standard regulations and does deprive neither Canada nor the EU right to adopt own standard regulation. Standard regulation harmonisation is a global

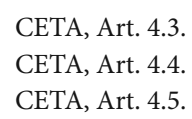

„... if a Party expresses an interest in developing a technical regulation equivalent or similar in scope to one that exists in or is being prepared by the other Party, that other Party shall, on request, provide to the Party, to the extent practicable, the relevant information, studies and data upon which it has relied in the preparation of its technical regulation, whether adopted or being developed."

7 CETA, Protocol on the mutual acceptance of the results of conformity assessment, Art. 2(5)e). 
process that can be observed within the UN and the WTO and is not a novelty in the EU-Canada relations.

\section{SANITARY AND PHYTOSANITARY MEASURES}

Similarly to TBT, the CETA complements WTO rules on sanitary and phytosanitary measures and confirm the obligation of the parties under SPS Agreement as annexed to WTO Agreement. Comparing to TBT, the parties committed themselves for mutual recognition of equivalence of SPS measures: "The importing Party shall accept the SPS measure of the exporting Party as equivalent to its own if the exporting Party objectively demonstrates to the importing Party that its measure achieves the importing Party's appropriate level of SPS protection."

However, even this recognition of equivalence does not mean duty of harmonisation of SPS rules and aims merely to recognize existing equivalent measures that can lead to simplification of import formalities.

\section{$4 \quad$ RIGHT TO REGULATE}

International trade agreements usually face criticism of offsetting regulatory power of states, binding regulatory stability and limiting democratic institutions in their ability to adapt national regulations in favour of their citizens. ${ }^{9}$ There appear suggestions that CETA could open the door to investors' claims against $\mathrm{EU}$ states because of employment of sovereign rights to change national regulatory regime. Usually Vattenfall, TransCanada, PhilipMorris or Bilcon cases are referred to as cautionary tales of exuberant demands of multinational corporations victimizing host states. ${ }^{10}$ Following issues are the main target of the criticism: investor protection and its legitimate expectation, inability to introduce environmental and labour standards and regulatory cooperation that enable multinational corporations to influence the preparation of regulatory framework in EU-Canada area.

In order to calm these objections Canada and the EU attached to the CETA Joint Interpretative Instrument on the Comprehensive Economic and Trade Agreement (CETA) between Canada and the European Union and its Member States (hereinafter "Joint Interpretative Instrument). Under Joint Interpretative Instrument "CETA preserves the ability of the European Union and its Member States and Canada to adopt and apply their own laws and regulations that regulate economic activity in the public interest, to achieve legitimate public policy objectives such as the protection and promotion of public health, social services, public education, safety, the environment, public morals, social or consumer protection, privacy and data protection and the promotion and protection of cultural diversity." It must be noted that even Joint Interpretative Instrument does not give full liberty in their regulation - their freedom is restricted to "regulation in the public interest" and

8 CETA, Art. 5.6(1).

9 For these objections see e.g. STIGLITZ, J. E.: Regulating Multinational Corporations: Towards Principles of Cross-Border Legal Frameworks in a Globalized World Balancing Rights with Responsibilities. American University International Law Review, vol. 23, issue 3, 2007, p. 451-558.

10 See e.g. CINGOTTI, N. et. al.: Investment Court System put to the test. Amsterdam/Brussels/Berlin/Ottawa, April 2016 [online] https://www.tni.org/files/publication-downloads/investment_court_system_put_to_the_test.pdf 
to "achieve public policy objectives". The CETA therefore does not recognize unfettered powers of regulators and aims more at ordo-liberal understanding the tasks of state.

\subsection{Investment protection}

Investment protection is always a neuralgic point of trade agreement because in the case of diminishing rights of investors, particularly via direct or indirect expropriation, actual or alleged, it can lead to substantial claims against states. The CETA introduced several conceptually brand new safeguards against abusive claims of investors:

First, it manifestly declares right to regulate: “...Parties reaffirm their right to regulate within their territories to achieve legitimate policy objectives, such as the protection of public health, safety, the environment or public morals, social or consumer protection or the promotion and protection of cultural diversity." ${ }^{11}$

Secondly, it is possible to regulate or change regulation to the detriment of investors: “...mere fact that a party regulates, including through a modification to its laws, in a manner which negatively affects an investment or interferes with an investor's expectations, including its expectations of profits." 12

Thirdly, the parties are in general free in their decision on subsidies: “... a Party's decision not to issue, renew or maintain a subsidy:

(a) in the absence of any specific commitment under law or contract to issue, renew, or maintain that subsidy; or

(b) in accordance with any terms or conditions attached to the issuance, renewal or maintenance of the subsidy,

does not constitute a breach of the provisions of this Section". ${ }^{13}$

Fourthly, it is possible to withdraw subsidy granted against domestic law: “...nothing in this Section shall be construed as preventing a Party from discontinuing the granting of a subsidy or requesting its reimbursement where such measure is necessary in order to comply with international obligations between the Parties or has been ordered by a competent court, administrative tribunal or other competent authority, or requiring that Party to compensate the investor therefor." ${ }^{14}$

Fifthly, the CETA introduces numerus clausus list of practices, which constitute breach of the obligation of fair and equitable treatment that can be extended by CETA Joint Committee only:

“...(a) denial of justice in criminal, civil or administrative proceedings;

(b) fundamental breach of due process, including a fundamental breach of transparency, in judicial and administrative proceedings;

(c) manifest arbitrariness;

(d) targeted discrimination on manifestly wrongful grounds, such as gender, race or religious belief;

(e) abusive treatment of investors, such as coercion, duress and harassment;..."15

11 CETA, Art. 8.9(1)

12 CETA, Art. 8.9(2).

13 CETA, Art. 8.9(3).

14 CETA, Art. 8.9(4).

15 CETA, Art. 8.10(2). 
Mere infringement of domestic law does not constitute infringement of fair and equitable treatment per se. ${ }^{16}$

Sixthly, general public policy regulations are excluded from terms of expropriation: “...except in the rare circumstance when the impact of a measure or series of measures is so severe in light of its purpose that it appears manifestly excessive, non-discriminatory measures of a Party that are designed and applied to protect legitimate public welfare objectives, such as health, safety and the environment, do not constitute indirect expropriations." ${ }^{17}$

Along these safeguards included into substantive provisions on investment protection, the CETA parties can influence the decision-making of tribunals deciding on investors' claims via interpretation rulings of the CETA Joint Committee ${ }^{18}$ that shall be binding for the tribunal.

From analysed provisions, it is evident that the EU and Canada tried to shrink manoeuvring space for non-legitimate investor claim., However, some notions are still open for further interpretation: "manifest arbitrariness", "fundamental breach of due process", "denial of justice”. On the other hand, these concepts are immanent to principles of rule of law and therefore shall be observed in all actions of the actions of the EU and its members and in the case of infringement of these rules, everyone, including investor, deserves a compensation. While due process, non-arbitrariness, right for fair trial are legal requirements for functioning of modern state, link between regulation and legitimate goals, its necessity and proportionality of regulation is a political question of the functioning of state. If citizens in their particular country accept or require policies and regulations that do not follow legitimate public policies, it can be considered out of the protection shell of Art. 8.9 CETA. Nevertheless, a regulation that is not following legitimate goals will still not constitute infringement of investors' rights if it does not fulfil criteria laid down for behaviour that is not fair or equitable or for expropriation.

\subsection{Environmental and labour standards}

The EU, as well as many European states, describe themselves as social market economies that respect protection of life environment. ${ }^{19}$ Hence, standards of protection of workforce and environment are essential for such policy. Gradual changes of labour protection standards and rules for protection of environment can be considered measures offsetting or diminishing investment or profit of a particular investment. Such changes can be sometimes very hard to estimate since they are connected with collective bargaining and technical development.

Protection of workers' rights and environment is two-fold:

First, the CETA confirms regulatory powers of the parties: the right of each Party to set its labour priorities, to establish its levels of labour protection and to adopt or modify its laws and policies accordingly in a manner consistent with its international labour commitments, is recognized. ${ }^{20}$ Reference to "international labour commitments" can be considered a limiting factor of changes of labour standard of respective Parties of the CETA. The question is, if the Party can regulate only in a way

16 CETA, Art. 8.10(7).

17 CETA, Annex 8-A, par. 3.

18 CETA, Art. 8.31(2).

19 See e.g. ŠMEJKAL, V.: The Social Market Economy Goal of Article 3(3) TEU - A Task for EU Law? In: Zborník z medzinárodnej vedeckej konferencie Bratislavské právnické fórum 2015, Bratislava: PraF UK, 2015, pp. 1519-1529.

20

CETA, Art. 23.2. 
following international agreements, commitments or other instruments or if such provision refers only to non-violation of international commitments requirement. Nevertheless, the CETA creates also a direction for future development of labour law setting minimal standard framework (obligations of the members of the International Labour Organization and the commitments under the ILO Declaration on Fundamental Principles and Rights at Work and its Follow-up of 1998 adopted by the International Labour Conference at its 86th Session) ${ }^{21}$.

Similarly, the CETA recognises Parties' the right to "set its environmental priorities, to establish its levels of environmental protection, and to adopt or modify its laws and policies accordingly and in a manner consistent with the multilateral environmental agreements ..." and the CETA. ${ }^{22}$

Furthermore, parties of the CETA have the legal obligation to "seek to ensure that those laws and policies provide for and encourage high levels of ... protection, and shall strive to continue to improve such laws and policies and their underlying levels of protection" in both areas - labour protection and environmental protection. ${ }^{23}$

Secondly, as a counterpart to the right to regulate in favour of increasing level of protection of workers' rights, the parties of the CETA prevented from decreasing the level of standards in labour and environment protection ${ }^{24}$. Despite the title of Art. 23.4 and 24.5 "Upholding levels of protection parties to the CETA are not obliged to uphold a level of protection of labour and environment in general. The CETA prohibits to "waive or otherwise derogate from, or offer to waive or otherwise derogate from, its ..." labour law and standards of environmental law “..., to encourage trade or the establishment, acquisition, expansion or retention of an investment in its territory." ${ }^{25}$ Moreover, parties are not only obliged to uphold labour protection and environmental laws but also effectively enforce them. However, again vis-à-vis trade and investment, only ("A Party shall not, through a sustained or recurring course of action or inaction, fail to effectively enforce its labour law and standards to encourage trade or investment", and mutatis mutandis environmental laws). ${ }^{26}$

Although the CETA acknowledges the right to introduce environmental laws, the parties shall be cautious in cases when such measures can affect trade between parties. In these cases they are obliged to "take into account relevant scientific and technical information and related international standards, guidelines, or recommendations" 27 . Paraphrasing this provision, parties to CETA cannot introduce environmental law affecting trade if they are not based on scientific and technical information. Precautionary measures aimed to prevent environmental degradation can escape from this obligation: "where there are threats of serious or irreversible damage, the lack of full scientific certainty shall not be used as a reason for postponing cost-effective measures to prevent environmental degradation“ ${ }^{28}$

21 For the list of these requirements see CETA, Art. 23.3.

CETA, Art, 24.3.

23 CETA, Art, 23. and Art. 24.3.

24 CETA, Art. 23.4 and Art 24.5.

25 CETA, Art. 23.4(2) and Art. 24.5(2).

26 CETA, Art. 23.4(3) and Art. 24.5(3).

27 CETA, Art. 24.8(1).

28 CETA, Art. 24.8(2). 


\section{REGULATORY COOPERATION}

Chapter twenty-one of the CETA introduces framework of regulatory cooperation and prudently the right to regulate is confirmed ${ }^{29}$. The wording of CETA also confirmed voluntary basis for regulatory cooperation (moreover obligation to "be prepared to explain the reasons for its decision to the

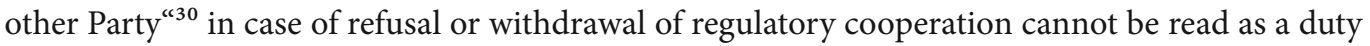
to give legitimate reasons). Due to strict voluntary basis for regulatory cooperation, rules on objectives of cooperation and regulatory cooperation activities ${ }^{31}$ do not establish any further obligation for parties. Similarly, under Art. 21.5 CETA, parties can either consider the regulatory measures or initiatives of the other Party on the same or related topics or adopt „different measures or pursuing different initiatives for reasons including different institutional or legislative approaches, circumstances, values or priorities that are particular to that Party."

Specific area of regulatory cooperation (even though it is not included in chapter twenty-one) can be identified in mutual recognition of professional qualifications. ${ }^{32}$ Recognition of qualifications is not an obligation under the CETA and party can establish their qualification criteria for particular professions. The recognition is mandatory only if MRA (mutual recognition agreement) is adopted by the Joint Committee on Mutual Recognition of Professional Qualifications ("MRA Committee") in the form of decision and after notification to the MRA Committee by each Party of the fulfilment of its respective internal requirements. ${ }^{33}$

\section{ONE-WAY LIBERALIZATION}

The CETA requires free market access, national treatment (NT), most-favoured-nation (MFN) treatment in investment, ${ }^{34}$ providing services, ${ }^{35}$ particularly financial services, ${ }^{36}$ as well as removes performance and senior management requirements in investment and senior management requirements in financial services. Parties to the CETA established a vast list (more than 850 pages) annexed to the CETA of reservations regarding this liberalization requirements (Art. 8.15 - Investment, Art. 9.7 - Services, Art. 13.10 - Financial Services). Derogation from liberalization is not permanent and changes can be performed in one way. Exemption from free market access, NT and MFN applies due to

(a) an existing non-conforming measure that is maintained by a Party;

(b) the continuation or prompt renewal of a non-conforming measure;

(c) an amendment to a non-conforming measure to the extent that the amendment does not decrease the conformity of the measure, as it existed immediately before the amendment.

CETA, Art. 21.2

CETA, ART. 21.2(7).

31 CETA, Art. 21.3 and Art. 21.4.

32 CETA, Chapter eleven.

33 CETA, Art. 11.3(6).

34 Art. 8.4 for market access, Art. 8.6 for NT, Art. 8.7 for MFN.

35 Art. 9.6 for market access, Art. 9.3 for NT, Art. 9.5 for MFN.

36 Art. 13.6 for market access, Art. 13.3 for NT, Art. 13.4 for MFN. 
Henceforth the Party liberalizes sector or service, it cannot later renew restrictive measure in the future, even though it was existent at the date of force of CETA and included into reservations (only prompt renewal is allowed). Similarly, the Party cannot renew previous intensity of restrictive measure if it once raises compatibility with liberalization requirements.

In the case of domestic regulation on licensing requirements, licensing procedure, qualification procedure and requirements (chapter twelve) is liberalization pressure even stronger - derogation from application of CETA rules is applicable on existing rules only. ${ }^{37}$

\section{CONCLUSIONS}

Influence of the CETA on domestic regulation, offsetting regulatory powers, impossibility to introduce and enforce labour protection and environmental protection laws are one of the major objections against the CETA. The CETA itself as well as the EU and Canada via Joint Interpretative Instrument were very prudent to stress acknowledgement of untouched right to regulate. This regulatory autonomy vis-à-vis “threats” of investors' claims was also supported by numerus clausus list of practices that constitute behaviour that cannot be considered fair and equitable. On the other hand, regulatory autonomy of states is restricted to legitimate purposes. The power to regulate and impossibility to challenge regulation by investors is particularly evident from rules dealing with labour protection and standards and environmental law. It must be noted, however, if environmental law affects the trade between parties, they must be supported by outcomes of scientific and technical information what can, from the one side point of view, protect from unfettered arbitrariness, from the other point of view, can make every environmental regulation questionable.

The CETA does not contain "hard law" rules of mandatory harmonisation and it opens door for mechanisms for voluntary convergence, only, via regulatory cooperation. However, incentives for convergence of law in the fields of TBT, SPS and recognition of professional qualification can stem more from stakeholders than from legal obligations laid down in the CETA.

\section{Bibliography:}

CINGOTTI, N. et. al.: Investment Court System put to the test. Amsterdam/Brussels/Berlin/Ottawa, April 2016 [online] https://www.tni.org/files/publication-downloads/investment_court_system_put_to_the_test.pdf

ŠMEJKAL, V.: The Social Market Economy Goal of Article 3(3) TEU - A Task for EU Law? In: Zborník z medzinárodnej vedeckej konferencie Bratislavské právnické fórum 2015. Bratislava: PraF UK, 2015, pp. 1519-1529.

\section{Contact information:}

JUDr. Ing. Ondrej Blažo, PhD.

ondrej.blazo@flaw.uniba.sk

Univerzita Komenského v Bratislave, Právnická fakulta

Šafárikovo nám. 6

81000 Bratislava

Slovak Republic

37 CETA, Art. 12.2(3). 